\title{
The Politics of Commoditization in Global ICT Industries: A Political Economy Explanation of the Rise of Apple, Google, and Industry Disruptors
}

\author{
Kenji E. Kushida
}

Received: 31 October 2014 /Revised: 10 November 2014/

Accepted: 3 December 2014 / Published online: 13 February 2015

(C) The Author(s) 2015. This article is published with open access at Springerlink.com

\begin{abstract}
The global Information and Communications Technologies industry has experienced a rapid, radical reorganization of industry leaders and business models - most recently in mobile. New players Apple and Google abruptly redefined the industry, bringing a wave of commoditization to carriers and equipment manufacturers. Technologies, corporate strategies, and industry structures are usually the first places to look when explaining these industry disruptions, but this paper argues that it was actually a set of political bargains during initial phases of telecommunications liberalization, which differed across countries, that set the trajectories of development in motion. This paper shows how different sets of winners and losers of domestic and regional commoditization battles emerged in various ICT industries around the world. Carriers won in Japan, equipment manufacturers in Europe, and eventually, computer services industry actors rather than communications firms emerged as winners in the US. These differences in industry winner outcomes was shaped by the relative political strength of incumbent communications monopolies and their will to remain industry leaders, given the political system and political dynamics they faced during initial liberalization. The US computer services industry, which developed independently of its telecommunications sector due to antitrust and government policy, eventually commoditized all others, both domestically and abroad. This paper contends that a political economy approach, tracing how politics and regulatory processes shaped industry structures, allows for a better understanding of the underlying path dependent processes that shape rapidly changing global technological and industry outcomes, with implications beyond ICT.
\end{abstract}

Keywords ICT $\cdot$ Commoditization $\cdot$ Industry structure $\cdot$ Economic policy $\cdot$ Liberalization

JEL codes $\cdot \mathrm{L} 14 \cdot \mathrm{L} 22 \cdot \mathrm{O} 25$

K. E. Kushida $(\square)$

Shorenstein Asia-Pacific Research Center, Stanford University, Encina Hall E301, Stanford, CA 94305, USA

e-mail: kkushida@stanfordalumni.org 


\section{Introduction}

One of the most recent dramatic developments in global Information and Communications Technologies (ICT) industries has been the rapid, radical reorganization of industry leaders and business models in mobile communications.

New players abruptly redefined the industry. Apple, new to the mobile industry in 2007, transformed the functionality of mobile handsets with its iPhone and App Store. It created a new "dominant design" of touch screen smartphones and transformed handsets into platforms. Google, following on the heels of Apple, introduced its Android operating system (OS) in 2008 with its own app store, distributing Android free to manufacturers. Together, Android and Apple quickly displaced all other mobile operating systems and designs - the "smartphone revolution." Shortly thereafter, Apple and Google became among the world's valuable companies, both by market capitalization and cash holdings.

The fall of incumbent communications equipment firms was dramatic. In 2011, Motorola sold its mobile division to Google. It had been a leading manufacturer second only to Nokia in global market share, but it was unable to effectively compete with its smartphones. More shockingly, in 2013, Nokia, dominant worldwide for over a decade, sold its core handset business to Microsoft.

Apple and Google also pushed aside other value-added service business models. Japan's mobile industry had been a leader in value-added services, including mobile Internet platforms, downloadable apps, and Internet email for almost a decade before the advent of Apple's iPhone and Google's Android. It also had the world's most sophisticated mass-market handsets, although Japan's mobile industry had not globalized effectively. Yet, even in their home market, Japanese firms were pushed aside by Apple and Google.

What happened? The smartphone revolution was, in essence, a takeover of the mobile communications industry by the computer industry (West and Mace 2010; Pon et al. 2014). Mobile handsets transformed from "phones with enhanced capabilities" to "miniature computers with phone capabilities." This takeover by computing industry players is likely to spread dramatically, as the transformation of computing power from a scarce to an abundant resource (Kushida et al. 2015) enables an almost limitless expansion of the domains in which data can be gathered and processing devices embedded.

The expansion of computer industry players into new industries threatens incumbent players by radically accelerating the competitive logic of commoditization, which disrupts existing firms and business models. Mobile communications provides the most dramatic example of this.

Commoditization entails competition based primarily on price, with prices approaching costs, leaving little profit or economic rent for firms. Commoditization traditionally refers to products, but services can be commoditized as well. Moreover, commoditization does not necessarily imply an immediate drop in financial performance; for example, demand for commoditized services such as flat-rate mobile data provision may rise in the short run, or regulations could limit competition despite undifferentiated services. However, without valueadded strategies, firms' longer-term growth potential is limited, and innovation to drive the next round of value-added activity is unlikely to occur.

The smartphone revolution commoditized telecommunications carriers by reducing their offerings to commodity voice and data services. Carriers' own proprietary services lost value when consumers faced a wealth of smartphone apps that provided better functionality, regardless of carrier. The ecosystem of apps, platforms, and operating systems were controlled by Apple and Google rather than carriers. Carriers' previous offerings of simplified web surfing capabilities that required truncated versions of the World Wide Web were rendered 
obsolete by smartphones' capabilities to access the "real" web (West and Mace 2010). The rapid growth of smartphones did increase revenues for carriers as customers added data plans, but carriers effectively ceded the possibility offering value-added services to differentiate themselves.

The smartphone revolution also accelerated the commoditization of handsets. Since core functionality was controlled by the OS, and app stores provided a broad range of configurability, manufacturers were far less capable of differentiating themselves. Unlike previous generations of phones that competed on the basis of various designs and features, smartphone designs rapidly converged to large touchscreens, and hardware performance was differentiated primarily by how well it ran the OS, rather than distinctive features. The form factor of iPhones and Android-based handsets quickly converged, as did app store offerings for popular apps. Android handset manufacturers faced ever-decreasing margins, and only firms such as Samsung, which attempted to "outrun commoditization" continued to succeed, though under increasing pressure.

Since this wave of commoditization hit the mobile industry so dramatically, and is likely to spread into new domains such as energy, transportation, healthcare, medical devices, and others, it is worth understanding the origins of this trajectory of computer industry expansion more clearly. Put simply, what are the underlying technological and industry trajectories of development that led to this outcome of commoditization driven by the US computer industry?

New technologies, new management strategies, corporate organizations, and industry structures are often used to analyze these sorts of disruptions (Christensen 1997; Funk 2002; Gawer and Cusumano 2002; Jacobides et al. 2006; Tee and Gawer 2009). This paper, however, argues that if we look deeper into how industries were shaped and reshaped over time, it was actually a set of political bargains during initial phases of telecommunications liberalization, which differed across countries, that set the trajectories for everything elsetechnologies, corporate strategies, and industry structures.

This paper shows how different sets of winners and losers of domestic and regional commoditization battles emerged in various parts of the world as a result of differences in the politics of telecommunications liberation. Global competition was shaped by the interaction of these different sets of winners and losers.

Scholarship focused on technology, management strategies, and industry structures tend to treat political and regulatory factors as exogenous. This paper contends that a political economy approach, tracing how politics and regulatory processes shaped industry structures, allows for a better understanding of the underlying path dependent processes that shape global technological and industry outcomes.

\subsection{The Argument in Brief}

The core contention of this paper unfolds in two steps. First, it shows how different sets of winners and losers emerged in the telecommunications industries of Europe, Japan, and the US - the countries with the most developed telecommunications R\&D capabilities. In Europe, communications equipment firms emerged as industry leaders spearheading R\&D and the technological trajectory of ICT sectors. In Japan, carriers won, resulting in a specific form of industry and technological leadership in which the industry advanced rapidly along particular trajectories, but failed to transform domestic sophistication into global leadership. In the US, firms from the US computer industry emerged as winners, spreading into global markets, entering and dominating the traditional domain of telecommunications Table 1.

The second part of this paper traces the politics shaping the different sets of winners. It contends that during the initial politics of liberalization in the $1980 \mathrm{~s}$, incumbent monopoly 
Table 1 Winners of the commoditization battles across countries/regions

\begin{tabular}{lccc}
\hline & US & Japan & Europe \\
\hline Computer & $\checkmark$ & $\checkmark$ & $\checkmark$ \\
Telecom Carriers & & $\checkmark$ & $\checkmark$ \\
Communications Equipment & & & \\
\hline
\end{tabular}

telecom carriers with the greatest political leverage and interest to dominate the sector, given the local political and institutional system, won. The politics of telecommunications liberalization unfolded as follows:

The US moved first, and the incumbent AT\&T was in the politically weakest position despite strongly desiring to maintain its dominant position. Once antitrust suits were brought by the Department of Justice, it had little political recourse. The resulting settlements broke apart the firm in the early 1980 s.

The Japanese incumbent, NTT, was politically strong and keenly interested in continuing its dominance. NTT held a privileged position in the country's clientelistic political system, exercising its political muscle during political battles over liberalization in the early 1980s. It succeeded in avoiding a breakup, retaining its $R \& D$ and financial resources that enabled it to shape the industry and propel its rapid technological advancement even after competition was introduced.

In Europe, the UK was the only liberalizer in the 1980s, but the incumbent was performing poorly and was not interested in consolidating resources or leading the sector's development. It did not resist politically driven liberalization, which weakened domestic equipment firms. France and Germany did not liberalize until the 1990s, providing an opening for Nordic firms to emerge as winners when mobile communications became the growth-driver from the 1990s.

The European, Japanese, and US telecommunications industries were commoditized by actors from the US computer industry, which arose from a separate but closely related regulatory context. While often depicted as market actors in a free entrepreneurial environment, the US computer industry actually owed much of its independence and dynamism to US telecommunications regulation and the liberalization process. The nascent computer and networking industry was protected from domination by telecommunications incumbents, and was also subject to antitrust that facilitated the rise of new firms and disruptive business models. The Internet originated as a government program and was carefully handed off to commercial management, and the broader US institutional structure that enabled the rise of venture capital and the Silicon Valley entrepreneurial ecosystem fueled the structural opportunities put into place by the US telecommunications regulatory process. This paper therefore makes a claim that is not obvious to most observers and participants - that the rise of Silicon Valley commoditizers actually owes much of its origins to the US telecommunications liberalization process.

\section{Commoditization Battles: Winners and Losers}

This section traces how different sets of winners and losers emerged in each of the telecommunications industries. The next section will show why these patterns emerged. To show how different set of winners and losers emerged, this section traces the effects of three major waves of ICT disruption: 1) initial liberalization, 2) the Internet's rise as a global open platform, and 3 ) the growth of mobile communications. Each entailed a reorganization of industry and 
business models, with incumbents facing intense commoditization pressures from new entrants bearing new technologies and business models.

\subsection{US Telecommunications}

The US was first to liberalize telecommunications. Intense competition rapidly lowered prices, commoditizing the incumbent's previously value-added services and capabilities. AT\&T was broken apart in 1984, with regional local telephone de facto monopolies ("Baby Bells") splitting off. AT\&T retained long distance, the world-renowned Bell Laboratories, and equipment manufacturing arm Western Electric. However, aggressive new entrants such as Qwest and WorldCom radically reduced long distance prices. Bell Laboratories, though a world leader in basic and applied research, inventing transistors, motion pictures, television, stereophonic sound, and laser technology, was seen as weak in commercializing that research while competitors focused on delivering low priced commodity services. Western Electric, later spun out as Lucent, initially relied heavily on legacy sales to Baby Bells, but AT\&T's competitors preferred non-AT\&T related equipment vendors, enabling Canadian firm Nortel to grow in tandem with AT\&T's competitors (Lazonick and March 2011) Fig. 1.

The advent of the Internet in the mid-1990s further commoditized carriers and displaced incumbent equipment manufacturers. New entrants began using the Internet backbone to carry voice data, bypassing existing telephony networks and further lowering long distance prices. Carriers were pressured to become "dumb pipes" providing only Internet connectivity; owning the infrastructure did not confer any additional advantage for their own services or content.

The real winners of the advent of the Internet were content and services firms. Amazon, eBay, Google, Salesforce.com, Yahoo, and other 1990s Internet startups grew out of the Silicon Valley business environment, with venture capital funding. Carriers and infrastructure firms became caught up in a speculative bubble that led them to invest massively into fiber optic infrastructure and Internet-related business activities (Kenney 2003). When the bubble burst in 2000-2001, the strong Internet startups survived and later thrived, but weaker startups and incumbent carriers relying more on financial investments than new value-added businesses did not. MCI WorldCom, AT\&T's largest competitor, declared bankruptcy in 2002.

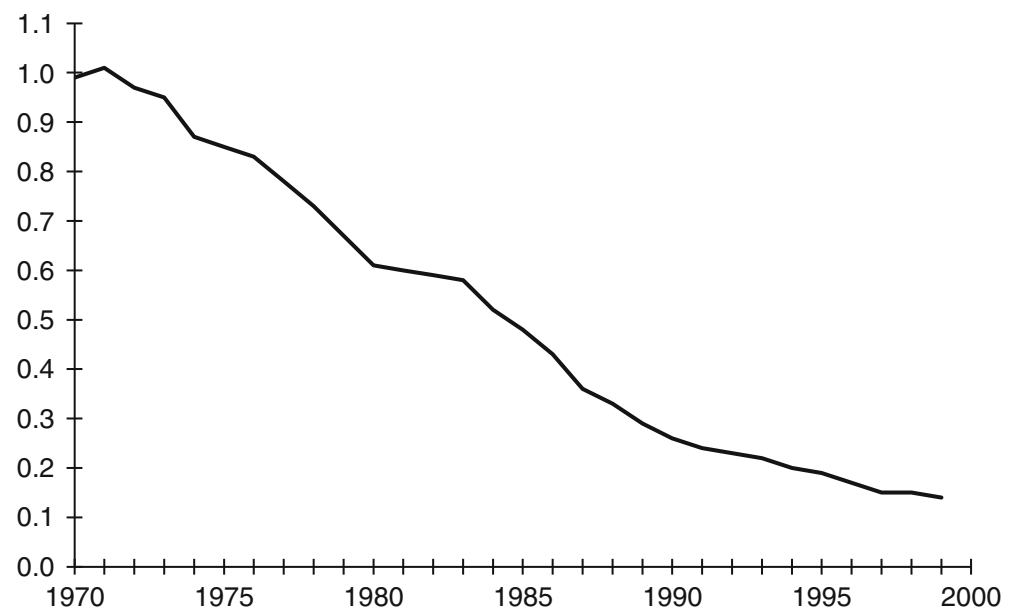

Fig. 1 US Industry average revenue per minute for interstate and international calls source: (FCC 2001) 
Explosive demand for Internet backbone infrastructure equipment was largely captured by Silicon Valley startup Cisco Systems, displacing incumbent communications firms. Cisco surged into global leadership, taking advantage of incumbent equipment firms being blindsided by the different design paradigm of Internet protocols underlying the Internet (discussed further later). Lucent faced plummeting sales; in 2000 it had been larger and more profitable than counterparts Nortel (Canada), Alcatel (France), and Ericsson (Sweden), but in 2006 it sold itself to Alcatel (Lazonick and March 2011).

In mobile, US carriers and equipment manufacturers lagged behind Europe and Japan. The US cellular industry had fragmented with the AT\&T breakup, with cellular business given to local carriers. American carriers spent billions of dollars and much of the 1990s re-unifying the cellular market (King and West 2002, as European firms expanded globally and Japanese carriers innovated with mobile Internet services. Neither AT\&T nor other US carriers were in a position to innovate and develop successful value-added services (King and West 2002). The disruption came in the late 2000s when computer industry players Apple and Google entered the mobile industry.

Thus, with liberalization, advent of the Internet, and diffusion of mobile, neither US incumbent carriers nor manufacturers were winners. Instead, US computer industry firms emerged as winners, spearheading high value-added business models.

\subsection{Europe's Telecommunications Industry}

In Europe, in essence, equipment manufacturers emerged as winners, particularly as mobile communications became the central growth driver. Carriers were increasingly commoditized. In the 1980s, the only major European liberalizer was the UK, in which neither carriers nor equipment manufacturers emerged as winners. France and Germany, until liberalization in the late 1990s, retained traditional vertically integrated industry structures of national carriers and a closed set of equipment manufacturers prioritizing single national champion firms. This provided room for specialized Nordic firms Nokia and Ericsson to emerge with the growth of mobile.

Liberalization in the 1980s was a UK story. British Telecom was split off from the Post Office in 1981 and privatized in 1984. Competition was introduced 1984, though cautiously, with a landline duopoly until 1991 limiting price decreases. Yet, despite avoiding price wars, British Telecom was unable to effectively pursue value-added strategies through R\&D despite its historical R\&D capabilities. A major reason was that liberalization was partly motivated in the first place by the poor quality of the Post Office's telecommunications services. British Telecom initially attempted to develop new digital switches in the late 1970 by leading British manufacturers GEC, Plessey, and STC, but the results were disappointing (Hulsink 1999). The company divested from manufacturing in 1990, procuring equipment from mostly foreign suppliers, decimating the already declining UK communications equipment sector.

European firms were not the primary beneficiaries of the advent of the Internet. Although CERN (the European Organization for Nuclear Research) researchers invented the World Wide Web, enabling easy use of the Internet, Europe's PC and networking diffusion was slower than the US. Without a large group of lead users, and with telecommunications carriers rather than startups playing central roles in the ICT sector, European firms did not drive innovations or capture global markets in areas such as Internet infrastructure equipment, broadband technologies, or applications and content (Kenney 2003).

The growth of mobile, however, was a European success story-but not driven by the traditional "Big Three" R\&D-capable national carriers in the UK, France, and Germany. While each "Big Three" incumbent deployed its own proprietary analog cellular standard, Nordic 
equipment firms Nokia and Ericsson gained early experience deploying the trans-national Nordic Mobile Telephone (NMT) standard. They became deeply involved in European standard-setting bodies developing the GSM digital standard in the late 1980s and early 1990s. GSM unified Europe's mobile markets and was rapidly adopted worldwide, enabling Nokia and Ericsson to surge into global markets.

Carriers adopting GSM were commoditized by not controlling the technological trajectories of development; they competed on price, and offering popular handsets. The relative R\&D intensity of carriers dropped precipitously as the locus of R\&D shifted to equipment manufacturers - evidence of manufacturers rising as winners leading the industry. Carrier strategies focused on increasing subscribers through domestic expansion and overseas M\&A, relying on Short Message System (SMS) to drive revenue rather than invest heavily in new mobile Internet services. While some efforts to develop mobile Internet services in the late 1990s focused on a standard known as WAP (Wireless Application Protocol), WAP services were plagued by inconsistencies such as incompatibility between handsets and carriers' features, creating poor user experiences. Carriers relied on services. Carriers' mobile Internet strategy options were limited anyway, since they required Nokia or Ericsson to implement their services. Dominant Nokia, unsurprisingly, prioritized its own music download and application store services not beholden to any particular carrier. The result was Europe's failure to deliver wireless Internet services, contrasted with Japan's successes (Funk 2002; Tee and Gawer 2009).

Thus, by the time that mobile communications was driving the sector in the late 1990s, the clear winners in Europe were the equipment firms - particularly Nokia-which dominated global markets until the late 2000s.

\subsection{Japan: Dominance of Carriers}

In Japan, carriers were the winners, remaining dominant over equipment firms. They set technological trajectories, spearheaded R\&D efforts, and developed the value-added services implemented by handset manufacturers.

Liberalization began in 1984, with the incumbent Nippon Telegraph and Telephone (NTT) partially privatized with competition introduced. NTT avoided being broken apart, retaining its R\&D capabilities, considerable financial resources, de facto monopolies over local telephony, its long distance, and other areas such as data services. Competition was limited, with strong government controls regulating new entrants, price levels, and firms' scope of business Fig. 2.

Japanese equipment manufacturers depended on NTT's technological leadership and procurement orders. A closed group of suppliers, known as "NTT family" firms, included Japanese industrial giants NEC, Fujitsu, Hitachi, and Oki Electric, and a tier of smaller manufacturers. NTT's procurements implicitly subsidized manufacturers' broader R\&D efforts through "cost-plus" basis procurement pricing, making them dependent on NTT (Anchordoguy 2001).

The Japanese telecommunications industry was relatively closed from global markets until the 1990s, with restrictions on foreign carriers and equipment. In this closed context, NTT's strong R\&D leadership and close cooperation with suppliers, who competed against one another intensely for procurement orders through quality improvements, facilitated Japan's rapid technological advancement (Fransman 1995). Yet, as Japan later discovered, when the carriers' trajectories diverged from global markets, manufacturers became isolated as well.

The advent of the Internet did not shift the balance of power between carriers and manufacturers. International service prices plummeted with new entrants patching calls 


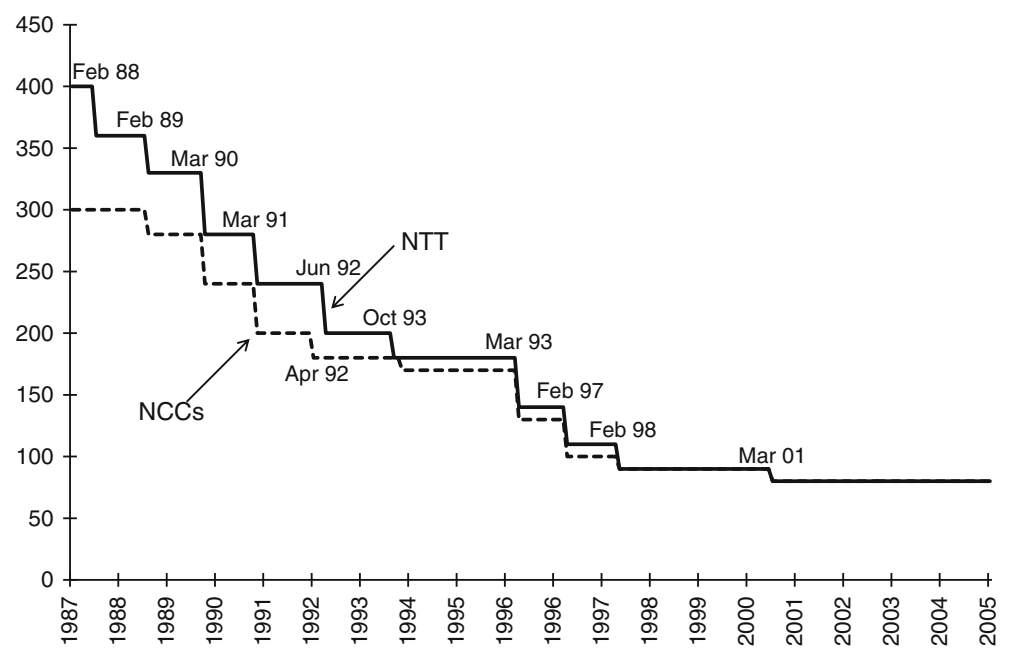

Fig. 2 Japan's “lock step" long distance price decreases (yen per 3 min call) source: MIC

through the Internet. In equipment, NTT, also blindsided by the Internet design paradigm, had led manufacturers to develop the previous generation of switching technology, delaying their shift to Internet-related equipment even as demand exploded (Cole 2006; Kushida 2006).

Japan's mobile industry, driven by network carriers, developed value-added services that catapulted Japan to the forefront of mobile Internet and related services. NTT continually enhanced its proprietary digital cellular standard deployed in 1994, improving handset performance. Carriers led manufacturers to develop handsets customized for each carrier's services, with carriers purchasing manufacturer's entire production stock and operating retail. Equipment manufacturers competed against each other over design and feature implementation (Marukawa and Yasumoto 2010).

From the mid-1990s, the three major Japanese carriers raced to develop mobile Internet services, ending up with services similar to NTT DoCoMo's pioneering i-mode. The new business model entailed: a carrier-provided portal; revenue sharing with "official" content providers with carrier-integrated billing (ideas reappearing in Apple's iPhone App store a decade later); and open access to "unofficial" content anywhere on the Internet. Internet email became the killer application, providing most Japanese users with their first "always-online" experience.

The commercial success of Japan's mobile Internet service platforms led carriers to pursue further value-added strategies. Music download services (predating Apple's iPod and iTunes music store), Java applets (small downloadable programs predating Smartphone Apps), and other features required tight integration between handsets and carriers' services. Japan's carrier-dominated industry structure could deliver this integration (Kushida 2011).

The weakness of Japan's carrier-led model, however, was isolation from global markets. Sophisticated handsets were useless abroad since only Japanese carriers offered the services that the handsets were capable of. NTT DoCoMo did attempt overseas expansion, but discovered that introducing value-added services in equipment firm-dominated European and (neither dominated) US markets was difficult. Since global-scale handset firms, especially Nokia, pursued their own value-added services, they were uninterested in developing i-mode compatible handsets. Major carriers such as Vodafone also preferred their own (relatively unsuccessful) services or to retain revenue streams from text messaging, leaving DoCoMo to 
partner with smaller carriers seeking to escape commoditization. However, these smaller carriers lacked clout with global-scale manufacturers as well.

The experience of Britain's Vodafone in carrier-dominated Japan further illustrates the incompatibility of winner/loser configurations across regions. Vodafone quickly discovered that Japan's early adoption of third-generation $(3 \mathrm{G})$ networks required extensive Japan-specific investments to remain competitive. Moreover, Vodafone's array of "global market" handsets, despite produced by Japanese firms, proved far inferior to Japanese-market optimized handsets. Experiencing an exodus of subscribers Vodafone exited Japan in 2005.

Thus, Japanese carriers were industry leaders, particularly incumbent NTT, which led its "family" of suppliers, joined by consumer electronics firms Panasonic and Sharp, competing fiercely against each other. Neither liberalization, the advent of the Internet, or and the rise of mobile shifted the domestic winners away from the carriers as winners.

\section{The Politics of ICT Liberalization Shaping National Trajectories}

We now turn to why the patterns of winners and losers emerged - the computer industry in the US, manufacturers in Europe, and carriers in Japan. They were not simply market outcomes, but the result of specific political dynamics and regulatory structures established during each country or regional's initial telecommunications liberalization. Despite the diversity of political dynamics around the world, we can identify an underlying systematic pattern of telecommunications liberalization and its outcomes: telecommunications incumbents in the strongest political position and with the strongest will to lead the sector retained their industry leadership capabilities.

\subsection{Japan's Telecommunications Politics}

Japan's case is simplest in many ways, since we would expect incumbents with decades of dominance to have the political clout to retain industry leadership - and this is what happened.

The Japanese government spearheaded telecommunications as part of rapid industrialization. The Ministry of Communications (MoC) became the monopoly operator in 1889 , strategically orchestrating multiple private companies to compete in supplying equipmentthe basis of "NTT family" suppliers.

In the immediate postwar period, the Allied Occupation government split $\mathrm{MoC}$, responsible for wartime propaganda and media control, into the Ministry of Posts and the Ministry of Telecommunications. In 1952, just before the occupation ended, a political compromise between the Occupation and Japanese governments led NTT to become a public corporation. The Ministry of Posts became the Ministry of Posts and Telecommunications (MPT) overseeing NTT.

NTT, monopolist from 1952 until 1985, dominated both industry and policymaking. A variety of legislative mechanisms to raise ample funding enabled it to lead equipment firms' R\&D (Fransman 1995; Anchordoguy 2001). MPT was a weak regulator, lacking expertise (MPT's telecommunications regulators were often seconded from NTT itself) and supervision powers. Politically, as one of Japan's largest companies NTT's massive number of employees and deep pockets provided political clout. Influence over politicians close to MPT was important because MPT controlled the postal saving system - the heart of Japan's porkbarrel politics providing investments for infrastructure projects used to gather rural votes by the Liberal Democratic Party, in power continuously from 1955 until 2008 and from 2011 onwards (Kawabata 2006). 
In the early 1980s, Japan's political leaders spearheaded liberalization of Japan's telecommunications industry, with Prime Minister Nakasone pushing deregulation of the largest stateowned enterprises of telecommunications, railroads, and tobacco. In the political battle, NTT fought to limit liberalization and avoid a break-up. While large corporate users wanted competition to lower prices, the massive "NTT family" firms feared losing procurement budgets. The political reform commission enjoyed broad popularity, pressing hard for liberalization and NTT's breakup. The powerful Ministry of Finance feared losing government income, aligned with LDP politicians close to MPT opposing a breakup. NTT's labor union, with 300,000 members and historical ties to the LDP's largest rival, the Socialist Party, opposed a breakup that could threaten members' livelihoods. It mobilized the Socialist Party to vigorously oppose a break-up. MPT saw the opportunity to expand its regulatory powers by controlling a liberalized industry, particularly in the area of data processing and software, over which MPT was bitterly contesting against the Ministry of International Trade and Industry (MITI) - but an NTT break-up was secondary.

After years of debate, NTT emerged relatively unscathed. Limited liberalization gave MPT regulatory powers to micromanage the sector and the 1985 settlement postponed the NTT breakup to 1990. In 1990, MPT pressed to breakup NTT, while NTT, MITI, the NTT Union, and MOF opposed. A stalemate postponed the issue to 1995, although the settlement did spin out NTT's wireless division into a wholly owned subsidiary, NTT DoCoMo. DoCoMo received NTT's extensive wireless labs, despite some MPT trepidation that DoCoMo would become too powerful; DoCoMo did indeed leverage its R\&D resources to shape the domestic playing field in its favor (Kushida 2011).

The 1995 debate pitted NTT's competitors and major industrial firms preferring a breakup, against NTT, NTT's union, the Socialist Party, and "NTT Family" firms. In 1996, NTT and MPT agreed to restructure NTT into a holding company, with wholly owned subsidiaries for local telephony (NTT East and NTT West), long distance and international service (NTT Communications), data and computing (NTT Data), and mobile (NTT DoCoMo) (Kushida 2011). In subsequent years, despite occasionally re-emerging, political discussions about breaking apart NTT went nowhere (Kushida 2013).

Thus, NTT's political power enabled it to retain resources for industry leadership despite numerous attempts by various actors to weaken it.

\subsection{Europe's Politics of Telecommunications Liberalization}

In Europe, liberalization processes were heterogeneous, but the relevant questions are why the UK incumbent carrier did not become the industry leader, and why France and Germany's incumbents did not emerge as winners in mobile despite their longstanding R\&D capabilities, ceding leadership to Nordic equipment manufacturers. The answers are that in the UK, the incumbent not only faced strong political pressure for liberalization, but it also had little interest in retaining industry leadership. In France and Germany, the politics surrounding telecommunications were not focused on liberalization, but rather consolidation-just as liberalization in the US, Japan, and the UK were reshaping the industry worldwide. Since the opportunities arising from liberalization were unexpected, particularly in mobile, this left room for the rise of Nordic firms specializing in mobile.

\subsubsection{United Kingdom}

In the UK, the British Post Office consolidated its monopoly in the early 20th century after several public debates and a court battle. In the postwar period, Great Britain's 
telecommunications industry suffered from insufficient funding. The operator became a public corporation in 1969, but in contrast to Japan's NTT, the British General Post Office faced strict financing constraints imposed by the Treasury, which also kept telephone rates low to combat inflation. Thus, by the mid-1970s, the Post Office ran a financial deficit and consumers complained of poor service and slow network buildouts (Vogel 1996; Hulsink 1999). It could not lead the sector in the manner of NTT.

Great Britain's equipment manufacturers were organized into a cartel-like arrangement until the 1960 s, but they were unable to become internationally competitive. In the 1960s, the Labour government spearheaded mergers among British equipment firms, further weakening them (Vogel 1996).

Liberalization was driven by Margaret Thatcher's Conservative Party, which came to power in 1979 embracing a mantra of neoliberal economic reform. Telecommunications was an ideal target.

There was very little political resistance against Post Office restructuring. Businesses supported liberalization, with the financial sector (City of London), in particular, concerned about international competition, demanding fast data communications (Hulsink 1999). There were multiple workers unions, and while the stronger Postal Engineering Union vigorously opposed privatization, it was weakened in the Parliamentary debate by supporting separating telecommunications from postal operations. The Department of Industry (DoI) lacked a coherent long-term mission, and unlike the bureaucracies of Japan, France, and Germany, it was not focused on protecting and developing domestic communications equipment firms (Vogel 1996). Therefore, DoI did not oppose liberalizing the equipment industry.

Following the British Telecommunications Act of 1981, BT emerged as a partially privatized operator in 1984, with a new independent regulator Oftel implementing and interpreting licenses to new competitors issued by the Department of Trade and Industry (DTI). After some notable failures in leading domestic firms to develop network switches, BT abandoned its traditional suppliers in favor of procuring equipment externally (Hulsink 1999). For a time, it moved directly into manufacturing for overseas markets, but in the early 1990s it sold its shares in manufacturing activities (Butler 1990). By the mid to late 1990s, BT had given up most of its $\mathrm{R} \& \mathrm{D}$ efforts, focusing instead on providing network services (Fransman 2002).

Thus, in the UK, when liberalization of the broader economy became a political priority, the telecom incumbent's poor performance led it to willingly become privatized and subject to competition, abandoning attempts to lead equipment manufacturers and spearhead R\&D. Neither the government nor incumbent were interested in keeping domestic equipment firms, opening the opportunity for foreign firms to supply all British carriers.

\subsubsection{France and Germany}

While political developments within the US, UK, and Japan were driving liberalization of their communications industries in the 1980s, the politics of France and Germany supported national monopoly carriers and national champion equipment firms.

Until the 1970s, France lagged substantially behind the UK and Germany in its telecommunications network and services. Spearheaded by President ValEry Giscard's administration in 1974, telecommunications was designated a national priority, allowing the national monopoly raise funding from capital markets. The R\&D and manufacturing capabilities of equipment firms, particularly national champion Alcatel, were strengthened by increasing the integration of ministry and operator - the reverse of other countries that were unbundling vertical integration at the time (Vogel 1996). 
Liberalization began gradually in the 1980s, largely out of the recognition that French equipment would need higher global market shares to survive (8-10\% versus the 3-4\% they had), combined with a move in the European Commission towards separating national regulatory authorities from operators. However, without major political, business, or user/ consumer groups pushing for radical liberalization, the monopoly Direction Générale des Télécommunications (DGT) itself led reform. DGT became France Telecom in 1988 with Direction de la Réglementation Générale (DRG) as the regulator. A reform bill in 1990 enabled competition in mobile, satellite, and other value-added services, with government regulations tightly controlling the sector. France Telecom was able to keep its vertically integrated structure and the industry focused on Alcatel as the national champion manufacturer (Vogel 1996). This enabled FT to roll out R\&D intensive, integrated service-hardware offerings such as the Minitel, but somewhat similar to the situation in Japan, these services struggled to internationalize.

In Germany, much like France, the Deutsche Bundespost (DBP) was an integrated government monopoly with a cartel of equipment manufacturers and R\&D centered around government organizations. Unlike the UK and France, DBP generally succeeded in providing universal service and quality services. Some technical difficulties in developing switching technologies forced DBP to adopt international digital standards, along with foreign equipment (Vogel 1996).

While the pressure for reform in Germany was far weaker than in the US, UK, or Japan, by the late 1980s German officials and businesses were concerned about the integrated monopoly's ability to offer advanced services. The US also pressured Germany for greater equipment procurement access, a concern for Germany's largest equipment firm, Siemens' US market access.

An independent inquiry commissioned by the government recommended the need for reform. Equipment providers were divided, and the postal workers union was opposed. The DBP shifted towards supporting reform, but resistance from unions led to concessions by the Helmut Kohl government in 1989. The reform law of 1990 detached DBP from the operator to create Deutsche Bundespost Telekom, with an Office of Welfare established within the DBP to protect workers' rights (Vogel 1996).

The DBP did actively foster competition, granting licenses to competing mobile and satellite operators, forcing DBP Telekom to provide low rate access to its network. With the integration of East Germany from 1990s, a key focus in the early 1990s was integrating, replacing, and building out the East German telephone network. In 1993, the government decided to partially privatize DBP Telekom beginning in 1996, providing Telekom access to capital markets and enabling it to engage in international M\&A. The overall characterization of the politics of Germany's telecommunications liberalization was one of pragmatic, piecemeal reform (Vogel 1996). As a result, the incumbent carrier was fairly domestic-oriented, limited in international opportunities until the late 1990s, and Siemens becoming a national champion equipment provider.

Now we turn to the US, which moved first in liberalization, and from which the computer industry produced firms that disrupted the entire communications sector.

\subsection{US Telecommunications}

AT\&T was the world's most technologically advanced and largest incumbent, but in liberalization debates, it was far weaker than Japanese and British incumbents. This was largely due to the political debate shifting to the US regulatory arena of the judicial branch, which was relatively immune to political lobbying. Moreover, AT\&T's confrontational political strategy backfired, causing it to lose political support. 
US regulations initially supported a monopoly, but also carefully limited AT\&T's business to telephony. US regulations developed in multiple policy arenas: state, federal, judicial, and legislative. AT\&T aggressively consolidated its competitors, partly through predatory pricing and refusing interconnection, emerging as a monopoly in the 1890s. In the 1910s, the US government's broad antitrust activities led to a Department of Justice (DOJ) suit against AT\&T. The resulting "Kingsbury Commitment" consent decree of 1913 granted AT\&T a de facto monopoly over telephony in exchange for divesting from telegraphs and allowing interconnection by competitors (Nuechterlein and Weiser 2005; Wu 2010).

Legislation by Congress, the Graham Act of 1921, formally recognized the rationale for telephony as a monopoly. The New Deal reforms of 1933, which targeted big businesses for breakup during the Great Depression, did not target AT\&T. In 1934, Congress passed the Communications Act, creating the FCC to oversee the sector. AT\&T emerged as the monopoly carrier, owning monopoly equipment manufacturer Western Electric and Bell Laboratories.

After World War II, the Truman administration brought a renewed focus to antitrust. Another DOJ antitrust suit resulted in a 1956 consent decree, allowing AT\&T to remain vertically integrated but restricting it to telephony; this prevented AT\&T from entering - and in all likelihood, dominating - the computer industry. The consent decree also enabled the equipment industry to develop independently by requiring Western Electric to sell equipment to AT\&T with independent accounting, and for Bell Labs to enter generous patent licensing agreements with other companies (Cohen 1992).

Federal policymaking through the FCC, beginning in the late 1960s, strengthened the principle of "modularity," allowing third parties to access and connect to AT\&T's network to conduct value-added activities independent of network ownership (Cowhey and Aronson 2012).

The FCC explicitly segmented the computer industry from the telephone industry in the 1970s with a series of decisions known as Computer I (1971) and Computer II (1976). Computer I separated data transmission, allowed by carriers, from data processing, allowed by everybody except carriers. Computer II redefined the categories, limiting carriers to "basic transmission," offering "enhanced services" through fully separated subsidiaries. The objective was to prevent the incumbent from leveraging its network to undermine enhanced service providers predatory pricing or denial of network access.

The FCC further facilitated competition against AT\&T in the 1960s and 70s, preventing what it saw as predatory pricing, and also permitting MCI to break AT\&T's long distance monopoly.

\subsubsection{Breakup of AT\&T}

The AT\&T breakup directly resulted from a 1974 DoJ antitrust suit, contending that AT\&T engaged in predatory pricing, restricted competition, and limited interconnection to competitors. DoJ also contended that AT\&T's relationship with Western Electric hindered competition in equipment manufacturing. The DoJ sought to divest Western Electric and local telephone companies from AT\&T (Cohen 1992).

AT\&T lobbied Congress intensely for legislative protection to restore its monopoly. Initial supporters included its labor union, several state-level utility commissions, and the US Independent Telephone Association. However, Presidents Ford, Carter, and Reagan all strongly supported competition and deregulation. AT\&T's large corporate customers wanted competition to lower rates, and public opinion was also against AT\&T. The computer industry, led by IBM, also opposed AT\&T's monopoly. AT\&T's political strategy backfired; the bill it pushed restricted competition so severely that even its initial allies turned against AT\&T, 
dooming its chances for legislative protection (Cohen 1992). Pressure from the judicial branch mounted in 1978 with a ruling on a separate antitrust suit filed by MCI, allowing long distance competitors to AT\&T.

AT\&T's massive size and financial position might have led it to a decisive legislative victory, although counterfactuals are never certain. However, when up against multiple antitrust suits, including one brought by the DoJ itself, AT\&T had little chance, and potential political supporters abandoned a losing battle.

AT\&T, recognizing it could not win, shifted course with new top management, focusing on a settlement to retain as many core activities as possible. It fought hard and successfully kept activities it perceived as most value-added: long distance and international services; R\&D; and equipment manufacturing. The resulting market segmentation prohibited local carrier Baby Bells from producing equipment and entering long distance or information services (data processing) (Cohen 1992). Critically, all parts of AT\&T were kept out of the rapidly growing computer industry, which by the 1980 s had begun to use long distance telephone lines for data communications.

Demonstrating the power of DoJ's antitrust compared to legislation, the 1996 Communication Act (the first major revision since 1923), was influenced by Baby Bells, allowing them to re-concentrate significantly. One group of Baby Bells took the AT\&T name, but it was no longer a business pursuing value-added through $R \& D$ or innovation.

\subsection{Development of the US Computer Industry, Data Communications, and the Internet}

Politics and regulations surrounding the development of the US computer industry protected from domination by telecommunications incumbents. Institutions surrounding the US Silicon Valley "model" of innovation, such as venture capital, deep university-industry ties, and factors conducive to entrepreneurial activity, in of themselves were not sufficient conditions for the rise of an independent computer industry.

The development of the US computer industry and the advent of the Internet are best treated as three separate, coexisting strands of development that converged in the 1990s: 1) the initial emergence of the computer industry dominated by IBM and the mainframe, 2) the rise of minicomputers and the PC, and 3) the development of the Internet.

\subsubsection{Mainframe: IBM Dominance, Limited by Government Policy}

The early computer industry was heavily shaped by military concerns, with massive postwar federal funding for R\&D and the military becoming a lead purchaser of computer systems. IBM emerged globally dominant from the 1950s through 1980s, in spite of measures to weaken it rather than from a government promotion strategy. For example, a 1956 Consent decree limited IBM from leveraging its service bureaus to drive sales. A second antitrust suit in 1965 viewed IBM's service, sales, and support as anti-competitive by locking in customers. Government procurement also sometimes avoided IBM, spreading procurement to states where IBM was not a major employer (Bresnahan and Malerba 1999). In other advanced countries, unlike the US, communications equipment firms generally were the computer firms.

\subsubsection{Mini/Microcomputers: Entrepreneurial New Entrants}

The rise of PCs as the world's dominant computing paradigm was driven by a new set of American firms - again, with the notable absence of telecommunications carriers and communications equipment firms. In the mid-1960s, DEC and new firms including Hewlett 
Packard and Varian Labs introduced "minicomputers," for technical problem solving, focused on specific applications (Bresnahan and Malerba 1999). These new firms, supported by venture capital, enjoyed first mover advantages globally, since both European and Japanese firms were focused on mainframes, as supported by their respective governments' policies (Kenney 2003). The next step in computer evolution, microcomputers, began appearing in the late 1970s from Silicon Valley based firms, most notably Apple.

The IBM PC, introduced in 1981, embraced a new design paradigm of modularity. Rather than provide all components as proprietary, in-house offerings like mainframes with integrated hardware and software, IBM orchestrated third party firms to provide crucial componentsmost notably Intel processors and a Microsoft operating system. This modular design ushered in an entire new industry structure and production paradigm — not only for computers, but for industrial production more generally (Borrus and Zysman 1997). Critically, the PC's open architecture enabled the rise of industries of PC-compatible components manufacturers and software makers, shifting the value away from final assemblers.

IBM's dominance in business computing gave way to a variety of independent, specialized firms; telecom carriers and equipment firms were notably unsuccessful. As offices became networked internally, the Internet emerged as an open global platform connecting various networks around the world. This is when the arc of computer industry development and adoption merged with the development of the Internet, which had been pursuing its own, highly government-shaped trajectory.

\subsubsection{The Development and Rise of the Internet}

The Internet began as a US military research program, later transferred to the National Science Foundation (NSF). After its management was handed off to the private sector in 1995, the Internet burst onto the global scene as an open global platform, connecting previously disparate networks around the world. The point is that the Internet, which disrupted telecommunications carriers and equipment firms worldwide, was created almost entirely outside the world of telecommunications, from specific US political economic conditions. Critically, the hand off to private sector management was handled carefully to avoid telecom carriers exerting control.

The Internet's design paradigm, based on defense considerations, differed fundamentally from telephony. This made it more amenable to becoming an open global platform and disrupting incumbent communications equipment firms. First, the Internet was decentralized, structured as a "network of networks" to which a variety of networks could interconnect so it could withstand a major (nuclear) attack. Telephone networks, in contrast, were centralized and coordinated as a single network. Second, with the Internet, system intelligence resided in the "edge" - in the computers attached to the network - with relatively simple network equipment. Telephone networks put intelligence in the network itself, with costly, centralized switching equipment. Cisco disrupted communications equipment firms by riding this fundamentally different Internet design paradigm.

ARPA (The Advanced Research Projects Agency), an organization within the Department of Defense (DoD) created in 1958, developed the basis of the Internet. The US, galvanized by the fear of falling behind the USSR in the cold war technology race, poured massive resources into defense-relevant research, working closely with universities and corporations, spearheading the discipline of computer science. ARPANET began operations in 1969 with an informal governance structure, connecting multiple ARPA research sites in academic and corporate labs. Email became the killer application, and the mix of academic and military users shaping the network to serve their own diverse needs led to its popular adoption. 
International organizations and governments, heavily influenced by incumbent carriers, did attempt to exert control over the nascent Internet. For example, carriers attempted to force manufacturers to adopt a particular network standard to shift the balance of power away from US computer industry firms. However, the community surrounding the nascent Internet made critical design choices while the network was still managed by DARPA, allowing it to avoid domination by telecom carriers (Abbate 1999).

In 1987 ARPA managers chose to dismantle the aging ARPANET backbone and transfer the host connections to a network maintained by the National Science Foundation (NSF), which had its own supercomputer program and network. Critically, the network initially restricted commercial interconnection, even as commercial network services such as Compuserve and America Online, offering closed networks with proprietary content, grew rapidly in the 1980s and 1990s. For corporate users, by the mid-1980s, commercial email systems such as MCI Mail, AT\&T Mail, and Telenet's Telemail offered email functionality to connect employees located worldwide. The NSF terms of agreement included an acceptable use policy prohibiting commercial use of the Internet, preventing these rapidly growing commercial networks from connecting to the Internet and offering services. In 1995, the NSF privatized the Internet, handing off its backbone management to commercial firms. Networks from all over the world were rapidly interconnected, and with the development of the World Wide Web, the population of Internet users quickly exploded (Abbate 1999).

If the Internet had not been developed in the US, with critical handoffs to the government science research and commercial sectors occurring after AT\&T was broken apart, the outcome of battles over control of the Internet might have turned out very differently. Had telecom carriers dominated it, the Internet almost certainly would have developed into a closed, controlled network rather than an open, global network.

Sustained interventions by the FCC protected firms providing content and services over the Internet, keeping it as an open platform. It employed the principle of "network neutrality," prohibiting carriers owning the underlying networks to charge differentiated prices according to service providers. This guiding principle of separating the content layer from the network infrastructure services layer within the industry was a general orientation rather than an explicit strategy, but one that the FCC maintained it more or less consistently (Bar et al. 2000).

\section{Conclusion}

This paper opened with the observation that the global ICT industry has been recently been disrupted dramatically by firms originating the US computer industry. Communications firms, both carriers and equipment firms, have been commoditized; carriers having little potential to differentiate by offering value-added services beyond connectivity, and equipment increasingly becoming commodity offerings.

In answering the question of why these dynamics of competition unfolded, this paper showed that global ICT competition was comprised essentially of multiple different domestic winners interacting on a global stage. The core argument is that different sets of winners emerged out of telecommunications liberalization across countries, with carriers emerging dominant in Japan, equipment manufacturers in Europe, and eventually the computer industry in the US. To understand why this pattern of winners emerged, this paper contended that a systematic pattern could be identified in the political process of liberalization across countries and regions: those in which the incumbent monopolies possessed the strongest political capacity, combined with the will to influence liberalization processes, successfully remained 
industry leaders capable of shaping the technological trajectories and value-added business strategies.

In the US, the computer industry was protected from domination by telecommunications players through early antitrust actions by the judicial branch, and sustained government intervention. In contrast with computer industries in other advanced industrial countries, the US computer industry developed independently. Combined with other institutions in the US such as venture capital, the computer industry experienced waves of disruption, with new firms replacing incumbents several times, paving the way for the emergence of firms that took advantage of the Internet. The Internet itself grew out of a specific US context, with its transfer away from US government management occurring in a way that limited commercial influence, enabling it to become an open, global platform - aided by sustained government policy to prevent domination by network carriers. The confluence of these factors of independent computer industry, venture capital-funded waves of disruption, and the emergence of the Internet as an open, global platform enabled the latest commoditizers of Apple and Google to disrupt the global mobile communications industry.

A key contribution of this paper is its political economy approach to understanding critical dynamics of global competition. It recognizes that global competition often unfolds as actors shaped by particular national political economic contexts interacting on a global stage. Telecommunications liberalization is not the first place most analysts would look to explain the rise of Apple and Google, for example, but to get a deeper understanding, this paper contends that it is the right place to look. The implications are clear, since computer industry players have already moved into a variety of previously distinct, well-defined sectors such as advertising, cameras, video recorders, music players, and payments - and are poised to move heavily into areas such as healthcare, energy systems, transportation, and others. While industry and firm-level dynamics of competition such as platforms and discontinuous innovation are well known, this paper shows that the origins of many of these disruptions can be traced to national level political economic factors that shape industries.

The central challenge for firms in all countries is how to avoid commoditization and pursue value-added business strategies (Zysman 2014). Here too, this paper's analysis of the communications industry is useful; successfully cultivating high value-added business models, services, and equipment in of itself does not guarantee global success. If it did, Japan should have dominated global mobile communications worldwide - and some predicted this. However, the key lesson from Japan's experience was that when the domestic winners are network infrastructure firms, high value-added services and equipment can be trapped in the domestic market unless infrastructure firms are able to effectively expand abroad. Political dynamics enabled Japan's network carriers to become industry leaders, so for other industries around the world in which hardware, services, and network infrastructure will be tightly bundled, the question is who will be the winners to lead the domestic industry. Since many of the areas in which information technology has the potential to transform are highly regulated, such as healthcare, energy, and transportation, domestic and regional political dynamics are likely to shape the winners.

The manner in which capitalist systems evolve - another set of debates in comparative political economy (Streeck and Thelen 2005; Jackson and Deeg 2008) - also benefits from this analysis. The core driver of industry-level change is the dynamics of competition that can lead to the rise and fall of major firms and industries. These industry-level actors are also usually political actors. The way in which political economies evolve are often about political settlements between a variety of actors, in which potential industry losers can have a major voice in shaping regulations that protect them in a variety of ways. The story of US computer services industry firms disrupting others is in some ways about the success - though not strategically planned - of US anti-trust actions, delivered through the judicial branch rather 
than legislative branch of policymaking. As a system, therefore, evolution of the US model needs to be aware of differences across regulatory arenas that shape industry architectures and firm-level outcomes.

When the next set of disruptions driven by ICT-related industries occur-and they willthe foundations laid by this paper will provide a solid basis for a comparative political economy analysis.

Acknowledgments This research is a part of the ongoing collaboration of BRIE, the Berkeley Roundtable on the International Economy at the University of California at Berkeley, and ETLA, the Research Institute of the Finnish Economy.

Open Access This article is distributed under the terms of the Creative Commons Attribution License which permits any use, distribution, and reproduction in any medium, provided the original author(s) and the source are credited.

\section{References}

Abbate J (1999) Inventing the internet. MIT Press, Cambridge

Anchordoguy M (2001) Nippon Telegraph and Telephone Company (NTT) and the building of a telecommunications industry in Japan. Bus Hist Rev 75(3):507-541

Bar F, Cohen S, Cowhey P, DeLong B, Kleeman M, Zysman J (2000) Access and innovation policy for the thirdgeneration internet. Telecommun Policy 24:489-518

Borrus M, Zysman J (1997) Globalization with borders: the rise of Wintelism as the future of industrial comptetition. Ind Innov 4(2):141-166

Bresnahan TF, Malerba F (1999) Industrial dynamics and the evolution of firms' and nations' competitive capabilities in the world computer industry. Sources of industrial leadership: Studies of seven industries, pp 79-132

Butler D (1990) BT's poor exchange. Management Today, April, 1990

Christensen CM (1997) The innovator's dilemma: when new technologies cause great firms to fail. Harvard Business School Print, New York

Cohen JE (1992) The politics of telecommunications regulation: the states and the divestiture of AT\&T. Sharpe, ME

Cole RE (2006) Telecommunications markets in world markets: Understanding Japan's decline. In: Zysman J, Newman A (eds) How revolutionary was the digital revolution? National responses, market transitions, and global technology. Stanford University Press, pp 101-124

Cowhey PF, Aronson JD (2012) Transforming global information and communication markets. Press, MIT

FCC (2001) Statistics of the long distance telecommunications industry. Federal Communications Commission, Washington DC

Fransman M (1995) Japan's computer and communications industry: the evolution of industrial giants and global competitiveness. Oxford University Press, New York

Fransman M (2002) Telecoms in the internet age: from boom to bust to...? Oxford University Press, New York

Funk JL (2002) Global competition between and within standards: the case of mobile phones. Palgrave, Basingstoke

Gawer A, Cusumano MA (2002) Platform leadership: How intel, microsoft, and Cisco drive industry innovation. Harvard Business School Press, Boston

Hulsink W (1999) Privatisation and liberalisation in European telecommunications comparing Britain, the Netherlands, and France. Routledge studies in international business and the world economy (Vol 14). Routledge, London

Jackson G, Deeg R (2008) From comparing capitalisms to the politics of institutional change. Rev Int Polit Econ 15(4):680-709

Jacobides MG, Knudsen T, Augier M (2006) Benefiting from innovation: value creation, value appropriation and the role of industry architectures. Res Policy 35(8):1200-1221

Kawabata E (2006) Contemporary government reform in Japan : the dual state in flux. Palgrave Macmillan, New York 
Kenney M (2003) The growth and development of the Internet in the United States. The global Internet economy, pp 69-108

King JL, West J (2002) Ma Bell's orphan: US cellular telephony, 1947-1996. Telecommun Policy 26(3):189-203

Kushida KE (2006) Japan's telecommunications regime shift: Understanding Japan's potential resurgence. In: Newman A, Zysman J (eds) How revolutionary was the digital revolution? National responses, market transitions, and global technology in the digital era. Stanford University Press, Stanford

Kushida KE (2011) Leading without followers: how politics and market dynamics trapped innovations in Japan's domestic "Galapagos" telecommunications sector. J Ind Compet Trade 11(3):279-307

Kushida KE (2013) Information and communications technology (ICT) policy in a post-LDP Japan: Caught between distributive politics and strategic policy again? In: Kushida KE, Lipscy P (eds) Japan under the DPJ: The politics of transition and governance. S-APARC, Stanford

Kushida KE, Murray J, Zysman J (2015) Cloud Computing: From Scarcity to Abundance. Journal of Industry, Competition and Trade, forthcoming

Lazonick W, March E (2011) The rise and demise of lucent technologies. Business and Economic History OnLine 9

Marukawa T, Yasumoto M (eds) (2010). Keitai denwa sangyo no shinka purosesu: Nihon wa naze koritsu shitaka [The process of cellular phone industry evolution: why Japan became isolated], Yuhikaku

Nuechterlein JE, Weiser PJ (2005) Digital crossroads American telecommunications policy in the internet age. MIT Press, Cambridge

Pon B, Seppälä T, Kenney M (2014) One Ring to Unite Them All: Convergence, the Smartphone, and the Cloud. Journal of Industry, Competition and Trade, forthcoming

Streeck W, Thelen KA (2005) Beyond continuity: Institutional change in advanced political economies. Oxford University Press, New York

Tee R, Gawer A (2009) Industry architecture as a determinant of successful platform strategies: a case study of the i-mode mobile internet service. Eur Manag Rev 6:217-232

Vogel SK (1996) Freer markets, more rules: Regulatory reform in advanced industrial countries. Cornell University Press, Ithaca

West J, Mace M (2010) Browsing as the killer app: explaining the rapid success of apple's iPhone. Telecommun Policy 34(5):270-286

Wu T (2010) The master switch: the rise and fall of information empires. Alfred A. Knopf, New York

Zysman J (2014) Escape from the commodity trap: will the production transformation sustain productivity, growth and jobs? Eur Comm. doi:10.2777/48430 